\title{
EFFECT OF COMMUNITY PARTICIPATION IN FOREST CONSERVATION IN IKOM AGRICULTURAL ZONE OF CROSS RIVER STATE
}

THERESA LARRY BISONG, KALU IROHA OGBONNA AND ISA UMAR KYARI

(Received 11 November 2016; Revision Accepted 19 December 2016)

\begin{abstract}
The effect of community participation in forest conservation via participatory approach has recently become a global strategy to development. The general objective of the study was to assess the effects of community participation in forest conservation in Ikom Agricultural zone of Cross River State. The specific objectives include; to access the need for community participation in forest conservation, to ascertain the benefit of community participation in forest conservation and to identify the areas and levels of community participation in forest conservation Ikom agricultural zone comprises of Boki, Abi, Etung, lkom, Obubra and Yakurr local government areas. Three Local Government Areas, Boki, Etung and Ikom, were specifically used for the study because they are the main forest areas in the zone. A structured questionnaire was used to obtain data for the study, and it was validated b y research experts in the Department of Agricultural Extension and Rural Sociology, University of. Calabar, Calabar. The study respondents were selected using simple handling technique. Using the population frame of the various local government areas one hundred and one (101) respondents were selected from Boki local government area, eighty nine (89) from Etung local Government area and one hundred and ten (110) respondents from Ikom local Government area. A reliability test was conducted using split-half technique while Pearson product moment correlation was used to correlate the data obtained and a coefficient of $r x y=80$ was obtained. Data obtained were analyzed using descriptive statistics such as frequency tables, percentages and range. The result of the analysis showed that the local communities were in a better position to monitor the forest as they have better knowledge of indigenous methods of conservation of both plants and animal species in their forest. The result also showed a range of benefits derived from community participation which include; increase in food production, income generation and availability of raw materials. The study, therefore recommended that the government should design forest conservation programmes that are participatory, democratic and bottom-top, by integrating the local people in the planning, design and implementation of forest conservation activities.
\end{abstract}

KEYWORDS: Community Participation and Forest Conservation

\section{INTRODUCTION}

Forest conservation is the preservation, maintenance, sustainable utilization, restoration and enhancement of all species, breeds and strains of a variety of forest resources (plant and animal) especially those of economic, scientific and cultural interest to mankind for agriculture either at present or in the future (FAO, 2009). Community participation is the employment of local people to mobilize their people to make decisions, manage their resources and control the activities that affect their lives. Natural resources are of immense benefit to humanity as man depends on various forest and wildlife species for food, fuel, fibre, medicine and raw materials for a host of manufacturing purposes.

The contribution of local communities in the conservation of forest has been recognized by the international community. Agarwal (200i) argued that any effort to rehabilitate the environment must rely on village members and not the government officials to do the job, because rural people already have the knowledge. Not only does this knowledge include information about different species of animals and plants, their behaviour and uses, as well as information about the way in which different aspects of the forest ecosystem inter-relate. Local people play an important role in the maintenance of forest resources. Depending on a number of historical, social and ecological factors, indigenous communities amass an extraordinary core of knowledge about how to manage the forest and utilize it sustainably. Agarwal (2001) therefore, maintained that community participation will enable the government and nongovernmental organizations to explore and exploit these local wisdom and initiatives to better conserve and manage the forest According to him, when local people participate, they will contribute their wealth of knowledge about nature to the conservation process, but where they are excluded from the forestry development process, then their contributions and experiences are either lost or left unharnessed.

Plucknett (2006) observed that community participation in forest conservation has several positive effects. Some local people maintain mixed species pastures and thereby ensure food for their flock even during period of climate stress. Rural people in centres of crop diversity have nurtured a considerable degree of variety in their crop

Theresa Larry Bisong, Department of Agricultural Extension and Rural Sociology, Faculty of Agriculture, Forestry and Wildlife Resources Management, University of Calabar, Calabar, Cross River State, Nigeria.

Kalu Iroha Ogbonna, Department of Agricultural Extension and Rural Sociology, Faculty of Agriculture, Forestry and Wildlife Resources Management, University of Calabar, Calabar, Cross River State, Nigeria.

Isa Umar Kyari, Department of Crop Science, College of Agric, P. M. B. 1025 Jalingo, Taraba State, Nigeria. 
germplasm. Nigerian rural communities for instance, maintain forest crops and have wildlife adapted to a wide range of edaphic, topographic, climate and altitudinal conditions. Some groups of indigenous people are known to construct taxanomies of plants and animal breeds based on useful characteristics, and also compile information on forest species abundance and distribution. Many of these taxonomies are extensive. Peters (2003) observesd that if these local people are fully involved in environmental conservation, they could constitute important source of inspiration and knowledge to the forestry department. World Rainforest Monitoring Report (1997) further noted that local people participations in global forest conservation have yielded positive results over the years. Local people identify and classify useful plant and animal species, describe ecological communities in an environmental context, test and evaluate forest species for their useful potentials. Using this knowledge, local people design, test and develop mechanisms for transferring knowledge from one generation to the next. The community participation approaches are critical sources of insight into forest management principles that can be incorporated into more national complex intensive systems.

Djeumo (2001) outlined the following effects of community participation in forest conservation; enhancement of the contribution of forest to Gross Domestic Product; contributions to household income and employment for local populations. participation will boost supply of raw materials for forest products, enhancement of forest contribution to foreign exchange earnings, and create avenue for food supply to local people. Jimoh and Azeez (2002) reported that for thousands of people, forests are vital sources of food, medicine, raw materials and income which rural communities have made use of sustainably through participation. They maintained that participation of local people is the fundamental basis of community forestry the participation brings about both positive and negative effects, if local people control and manage their forests and are fully involved in all planning stages of forestry development and if benefits are properly shared, community participation can yield substantial local, regional and global benefits to the society.

However, Verheijden (1999) observed that power and other social relations within and between the state agencies, community groups and other actors involved in the conservation and use of natural resources intervene in the implementation of participatory conservation projects but their involvement can lead to unintended outcomes such as ethnic conflicts. Moreso, local people do not have enough knowledge on effective conservation thus contradicting goals of participatory project. Participation is time demanding and costly and some powerful elites within local communities may capture the benefits of participatory efforts and endanger participation by the less powerful groups.

In Nigeria, community participation in forest conservation is a way of achieving poverty reduction and improving rural livelihoods through sustainable forest utilization. It allows local people to be involved in managing the forest in which they live and upon which they rely for their livelihood and survival. Studies have shown that introduction of community forestry practices among forest communities has empowered them in various ways and such empowerment has affected their decision making processes, local governance, economies, farming practices, trade non -timber forest products and the communities in general. Involving communities in the management of forest resources have resulted in the promotion of the sustenance of traditional lifestyles and livelihood systems, meeting local needs and aspirations and sharing the benefit of forestry projects which invariably will contribute to rural development (Osemobo, 2001).

\section{RESULTS AND DISCUSSION}

Table 1 presents respondents' perceived reasons for participation in the maintenance and preservation of forest. Based on the expressed views, $66.01 \%$ of the respondents agreed that local communities are better placed to monitor and control forest activities, while $54.94 \%$ of the respondents believed that communities have better knowledge of plant and animal species that survive in their forest. It could be concluded that community participation in forest conservation would be highly effective when the local people are given full authority to monitor and control forest activities because they appear to have better knowledge and information about forest conservation, as well as animal and plant species dwelling in their forest. This supports the work of Djeumo (2001) that community participation in forest conservation contribute to gross domestic product, household income and employment for the local people. However, FAO (2001) contended that government's inability to collaborate and integrate local people into forest conservation activity is the main challenge of participatory forest management in Africa.

A wide range $f$ benefits derivable from communities participation in forest conservation presented in table 2, include promotion/enhancement of food production $(62.85 \%)$, boosting the supply of forest products/materials $(45.45 \%)$ and enhancing the income base of the people $(49.80 \%)$. From the point of view of the local people, fertile soils exist in association with forest resources, hence a well conserved/managed and sustainably utilized forest is likely to produce sufficient quantities of food especially using agro-forestry farming systems which involves the planting of food crops and forest trees simultaneously in the same piece of land. Another recognized benefit that comes through the participation of the community in forest conservation is helping the government in controlling forest exploration by foreigners (53.75\%). This is true because studies by Petty (1998) and Wilson (1998) maintained that the local people, when given full right to manage a forest, does it effectively as they live in or exist alongside the forest and can prevent foreign intruders unlike the government officials who reside in most cases at the state capital or local government headquarters and seldom visit the forest.

The study also investigated the areas of community participation in forest conservation and level of participation by the local people. According to data in Table 3, the respondents identified several areas where members of the community were involved in forest conservation which include: planning of forest management activities, enforcement of forest laws/, planting of new trees, seedlings and provision of land for forest activities. However, on the level of participation, it showed that the respondents participated more actively on the provision of land for forest activities/expansion (2.59) and planting of new trees seedlings (2.54) but less or not actively in decision making (1.28), funding of forest activities (1.28) and planning of forest management activities (1.38). According to FAO (2009), $80 \%$ of the world's forest reserves are situated on lands owned by local communities, for the purpose of nature conservation, implying that rural 
communities have remained the main donors of forest reserve areas and local labour is often utilized in forest establishment. Accordingly, Fisher (1999) affirmed/that most forests were established by communal efforts initiated and executed by the local people themselves, especially in Asia the Pacific and West Africa. It could be concluded based on the result of the analysis in this study, that community participation in forest conservation in the study area was mainly in the provision of land and planting of new trees seedlings, however, the people were not actively involved in the decision making on conservation matters, as well as on funding and planning of forest management activities. 
Table 1: Distribution of respondents based on the need for community participation in forest conservation

\begin{tabular}{|c|c|c|c|c|c|c|c|c|c|}
\hline & & Boki & & Etung & & Ikom & & Total & \\
\hline & Reasons for community participation & Freq. & $\%$ & Freq. & $\%$ & Freq. & $\%$ & Freq. & $\%$ \\
\hline A & Communities are in better position to monitor and control forest activities & 57 & 57.00 & 41 & 64.06 & 69 & 77.53 & 167 & 66.01 \\
\hline B & Have better knowledge and information about the forest conservation & 42 & 42.00 & 29 & 31.25 & 36 & 40.45 & 98 & 38.74 \\
\hline C & $\begin{array}{l}\text { Communities have better knowledge of wild plant and animal species that } \\
\text { can survive in different climate/topography }\end{array}$ & 40 & 10.00 & 47 & 26.56 & 52 & 13.48 & 139 & 54.94 \\
\hline D & $\begin{array}{l}\text { Communities have indigenous methods for conserving and maintaining } \\
\text { forest }\end{array}$ & 16 & 16.00 & 9 & 14.06 & 15 & 16.85 & 40 & 15.81 \\
\hline$E$ & $\begin{array}{l}\text { Communities are more effective in checking destruction of community } \\
\text { forest by foreigners }\end{array}$ & 28 & 28.00 & 17 & 26.56 & 21 & 23.60 & 66 & 26.09 \\
\hline$F$ & Communities control the extinction of plant and animal species & 9 & 9.00 & 3 & 4.69 & 12 & 13.48 & 25 & 9.88 \\
\hline
\end{tabular}

Table 2: Distribution of respondents according to the benefits associated with community participation in forest conservation

\begin{tabular}{|c|c|c|c|c|c|c|c|c|}
\hline \multirow[t]{2}{*}{ Benefits of participation } & \multicolumn{2}{|l|}{ Boki } & \multicolumn{2}{|l|}{ Etung } & \multicolumn{2}{|l|}{ Ikom } & \multicolumn{2}{|l|}{ Total } \\
\hline & Freq. & $\%$ & Freq. & $\%$ & Freq. & $\%$ & Freq. & $\%$ \\
\hline Creation of employment & 9 & 9.00 & 17 & 26.56 & 14 & 15.73 & 40 & 15.81 \\
\hline Enhancement of food production & 36 & 36.00 & 49 & 76.56 & 74 & 83.15 & 159 & 62.85 \\
\hline Boost supply of raw materials & 27 & 27.00 & 30 & 46.86 & 58 & 65.17 & 115 & 45.45 \\
\hline Increase the knowledge of indigenous people on conservation & 12 & 12.00 & 19 & 29.69 & 24 & 26.93 & 55 & 21.74 \\
\hline Communities help to maintain forest sustenance & 20 & 20.00 & 6 & 9.38 & 17 & 19.10 & 43 & 17.00 \\
\hline Ensure environmental protection & 21 & 21.00 & 31 & 48.44 & 10 & 11.21 & 62 & 24.51 \\
\hline To check indiscriminate deforestation & 19 & 19.00 & 23 & 35.94 & 30 & 33.71 & 72 & 28.46 \\
\hline To monitor control forest exploitation by foreigners & 30 & 30.00 & 41 & 64.06 & 65 & 73.03 & 136 & 53.75 \\
\hline Increases income of local people & 31 & 31.00 & 37 & 57.81 & 58 & 65.17 & 126 & 49.80 \\
\hline Promotion of foreign exchange earnings by the government & 11 & 11.00 & 16 & 25.00 & 21 & 23.60 & 48 & 18.97 \\
\hline $\begin{array}{l}\text { Enhances local people knowledge about the state of maintenance of } \\
\text { community forest }\end{array}$ & 19 & 19.00 & 23 & 35.94 & 30 & 33.71 & 72 & 28.46 \\
\hline
\end{tabular}


Table 3: Distribution of respondents based on areas and levels of community participation in forest conservation

\begin{tabular}{|c|c|c|c|c|c|c|c|}
\hline$S / n$ & Areas of participation & \multicolumn{3}{|c|}{ Levels of participation } & $\Sigma$ & $\mathrm{X}$ & Rank \\
\hline & & $\begin{array}{l}\text { Actively } \\
\text { involved } \\
\text { (3) }\end{array}$ & $\begin{array}{l}\text { Partially } \\
\text { involved } \\
\text { (2) }\end{array}$ & $\begin{array}{l}\text { Not } \\
\text { involved } \\
\text { (1) }\end{array}$ & & & \\
\hline I & Decision making & $6.93 \%$ & $14.23 \%$ & $79.05 \%$ & 323 & 1.28 & $6^{\text {th }}$ \\
\hline li & $\begin{array}{l}\text { Funding of forest } \\
\text { activities }\end{array}$ & $10.28 \%$ & $7.51 \%$ & $28.21 \%$ & 324 & 1.28 & $6^{\text {th }}$ \\
\hline iii & $\begin{array}{l}\text { Planning of forest } \\
\text { management activities }\end{array}$ & $11.86 \%$ & $13.83 \%$ & $74.34 \%$ & 348 & 1.38 & $5^{\text {th }}$ \\
\hline iv & $\begin{array}{l}\text { Enforcement of forest } \\
\text { laws/regulations }\end{array}$ & $15.81 \%$ & $13.04 \%$ & $71.15 \%$ & 366 & 1.45 & $4^{\text {th }}$ \\
\hline V & $\begin{array}{l}\text { Planting of new trees } \\
\text { seedlings }\end{array}$ & $62.06 \%$ & $30.04 \%$ & $7.91 \%$ & 643 & 2.54 & $2^{\text {nd }}$ \\
\hline vi & $\begin{array}{l}\text { Provision of land for } \\
\text { forest expansion }\end{array}$ & $58.89 \%$ & $41.11 \%$ & - & 655 & 2.59 & $1^{\text {st }}$ \\
\hline vii & $\begin{array}{l}\text { Provision of housing } \\
\text { facilities for } \\
\text { conservation staff }\end{array}$ & $14.62 \%$ & $26.09 \%$ & $59.29 \%$ & 393 & 1.55 & $3^{\text {rd }}$ \\
\hline
\end{tabular}

\section{CONCLUSION AND RECOMMENDATION}

Forests are of high economic value and plays important social, cultural, ecological, religious and political role in the lives of the citizens. Forest conservation has been recognized as the only viable avenue to ensuring the sustainability of global forests. However, host Communities have longed been seen as important partners in the conservation and management of forest reserves. Community participation in forest conservation in Ikom agricultural zone of Cross River State seems to be a complex process that is dependent on a wide range of factors such as government driven forest management and low participation of communities in the areas of planning forest management activities. As a result the communities have a perception that forest conservation is a government driven activity.

The study therefore recommends that Government should design forest conservation programmes that are community participatory, democratic and bottom-top by integrating the people in the planning, design and implementation of forest conservation activities. This will give the local people a sense of belonging and responsibility towards forest conservation.

\section{REFERENCES}

Agarwal, C. U., 2001. Sustainable forest management. Ecology 4(1):111-118.

Djeumo, S. A., 2001. Management of world biodiversity. Nairobi: Wisdom Press. Dosunmu, T. (2001). Agro-ecology conservation. Lagos: Freedom Publishers.

Fisher, R. J., 1999. Devolution and decentralization of forest management in Asia and the pacific. Conference paper 3-5.

Food \& Agricultural Organization., 2001. How forest can reduce poverty. Forest department policy brief. Rome: FAO.
Food and Agricultural Organization., 2009. A forester's guide for community involvement in upland conservation. Rome: FAO.

Jirnoh, S. O and Azeez, I. O., 2002. Prospects of community participation in the management OFshasha forest reserve, Osun state Nigeria.

Mjgar, D. A., Ojating, I and Aya, F. A., 2003. Community forestry and forest stakeholders' participation in Sustainable forest management. Paper presented at the $29^{\text {th }}$ Annual conference of Forest Association of Nigeria (FAN).

Osemobo. S. B., 2001. Building consensus in forest protection. In Williams, U. (Ed.), Environmental conservation in Africa. Ibadan: Independent Books.

Peters, R., 2003. Conserving Agro-biodiversity. Ibadan: University Press.

Petty, J. N., 1998. Using rapid rural appraisals. In B. E. Swanson. R. P. Bantz and A. J. Sofranko Improving agricultural extension - A reference manual. Rome: Food and Agriculture Organization, 123-321.

Plucknett, P. J., 2006. Development of social forestry in Nigeria. Ibadan: Hedimo-Litho Press.

Verheijden, T. N., 1999. The African rainforest. Cambridge: University Press.

Willson, E. O., 1998. The Current state f Biological diversity. Washington, DC: National Academy Press, 1097.

World Rainforest Monitoring (WRM) (1997). State of world forests. Washington. DC: World Bant. 
